\title{
Kepercayaan dan Pamali Nelayan Pulau Kambuno di Sulawesi Selatan
}

\author{
Andi Adri Arief ${ }^{\mathrm{a}, 1^{*}}$, Harnita Agusanty ${ }^{\mathrm{b}, 2}$, Muhammad Dalvi Mustafa ${ }^{\mathrm{c}, 3}, \operatorname{Kasri}^{\mathrm{d}, 4}$ \\ acd Universitas Hasanuddin, Jalan Perintis Kemerdekaan Km 10 Makassar, 90245, Indonesia \\ b Universitas Muhammadiyah Makassar, Jalan Sultan Alaudin No. 259 Makassar ,90221, Indonesia \\ 1*andi_adriunhas@yahoo.com; ${ }^{2}$ nita_komuna@yahoo.com; ${ }^{3}$ dalvimustafa@gmail.com; \\ ${ }^{4}$ kasrimuhammad219@gmail.com \\ * Corresponding Author
}

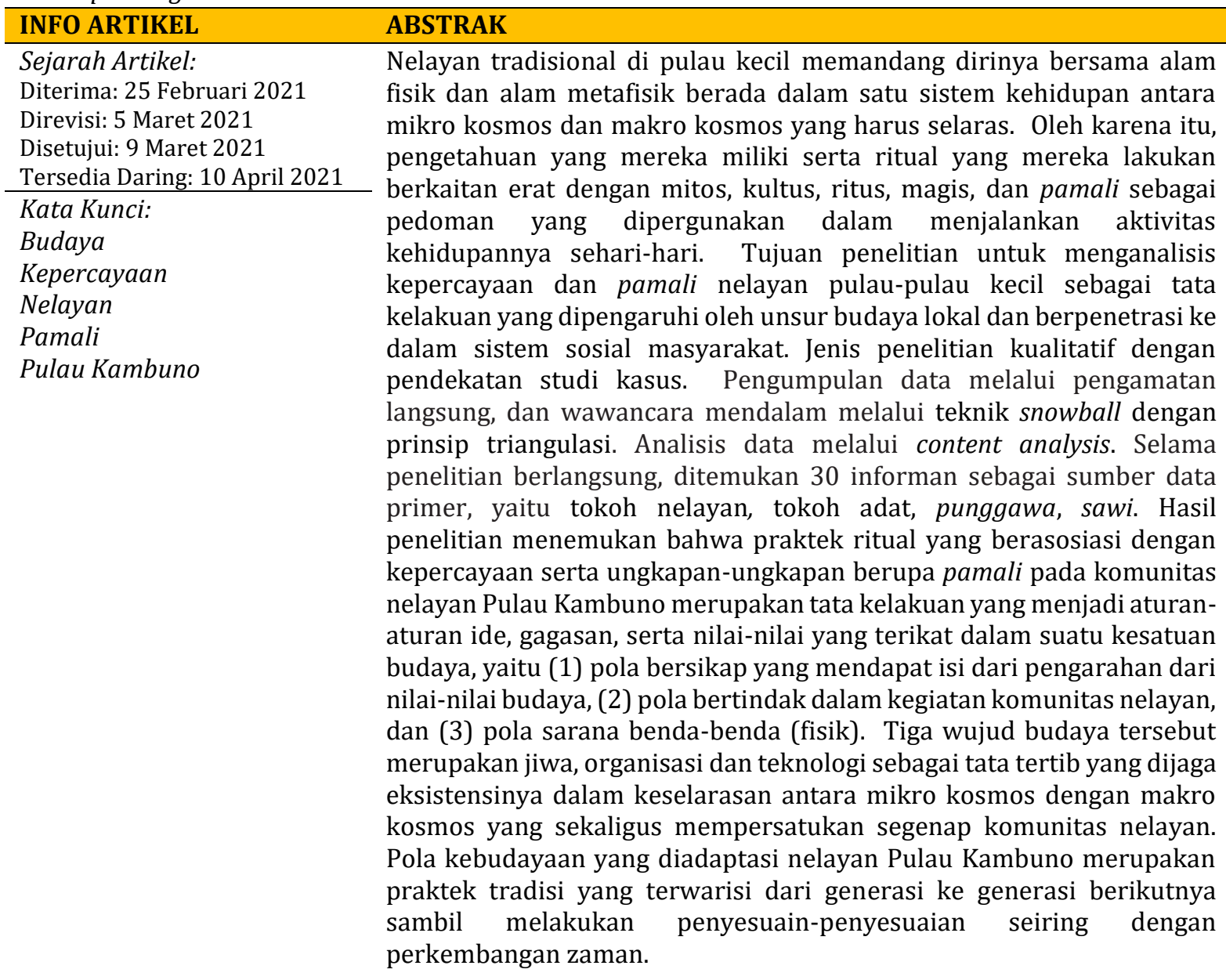

\begin{tabular}{ll}
\hline ABSTRACT \\
\hline Keywords: \\
Culture & Traditional fishermen in small island look at themselves with the physical \\
Belief & and metaphysical realms as being in a single system of life between the \\
Fishermen & micro cosmos and macro cosmos which must be in harmony. Therefore, the \\
Pamali & knowledge they have and the rituals they perform are closely related to \\
Kambuno Island & myths, cults, rites, magic, pamali as guidelines used in carrying out their \\
& daily activities. The research objective was belief analyze and pamali \\
& fishermen of small island as behavior that is influenced by local culture \\
& elements and penetrate into the social system of society. This type of \\
& research is qualitative with a case study approach. Collecting data through \\
& direct observation, in-depth interviews using snowball techniques with the \\
principle of triangulation. Data analysis through content analysis. During \\
the research, 30 informants were found as primary data sources, including
\end{tabular}


fishermen leader, traditional leaders, punggawa, sawi. The results of the study found that ritual practices associated with beliefs and expressions in the form of pamali in the fisherman community of Kambuno Island are behaviors that become rules of ideas, ideas and values that are bound in a cultural unity which includes, namely: (1) attitude patterns that get the contents of the direction cultural values, (2) patterns of action in fisherman community activities, and (3) patterns of means (physical) objects. Three forms of culture are the soul, organization and technology as an order which is maintained in harmony between the micro cosmos and macro cosmos which simultaneously unites all fisherman community. Adapted cultural pattern by the fishermen of Kambuno Island is a traditional practice which inherited from generation to next generation while making adjustments along with the times.

(c) 2021, Arief, Agustany, Mustafa, \& Kasri

This is an open access article under CC-BY license

(c) $\underset{\mathrm{BY}}{\mathrm{B} \mathrm{s} A}$

How to Cite: Arief, A. A., Agustany, H., Mustafa, M.D., \& Kasri. (2021). Kepercayaan dan Pamali Nelayan Pulau Kambuno di Sulawesi Selatan. Satwika : Kajian Ilmu Budaya dan Perubahan Sosial, 5 (2), 18-29. doi: 10.22219/satwika.v5i1.15816

\section{Pendahuluan}

Hakikat negara kepulauan terdiri atas pulau induk dan pulau-pulau kecil beserta laut sebagai wilayah untuk kehidupan serta pusat dari aktivitas manusia. Pulau kecil didefinisikan sebagai pulau yang luasnya lebih kecil atau seluas $2.000 \mathrm{~km}^{2}$ termasuk kesatuan dari ekosistem yang ada di dalamnya. Berdasarkan aspek ekologis, pulau kecil terpisah dari pulau induknya (mainland), mempunyai batas fisik wilayah yang jelas, kondisi wilayah yang terpencil cenderung terisolasi dari pulau induk, bersifat insular. Berdasarkan aspek sosial, budaya, dan ekonomi, memiliki ciri khas jika dibandingkan dengan kondisi pulau induknya (Arief et al., 2020).

Pulau Kambuno sebagai wilayah penelitian memiliki kondisi yang sama sebagai pulau kecil. Berbagai permasalahan dihadapi, seperti sistem produksi yang dominan tradisional, infrastruktur pulau yang masih terbatas, kapasitas sumberdaya manusia yang masih rendah (aksesibilitas terhadap pendidikan) serta layanan kesehatan yang masih minim merupakan permasalahan-permasalahan yang harus teratasi dari waktu ke waktu. Seberapa jauh masyarakat nelayan dan kebudayaan di pulau ini dapat mengalami perkembangan ke arah yang lebih baik banyak ditentukan oleh terjangkau tidaknya sistem pembangunan dan pengembangan kebudayaan maritim berdasarkan tuntutan perubahan zaman.

Dengan demikian, pembangunan maritim di pulau kecil sebagai proses perubahan secara berencana ke arah yang lebih baik hanya dapat terwujud dengan mengembangkan potensi yang dimilikinya. Potensi yang dimaksud adalah kompleks kemungkinan untuk berubah atau berkembang ke arah yang lebih baik. Selama ini, potensi yang banyak mendapatkan perhatian hanya fisik wilayah saja, padahal hakikat pembangunan adalah kerjasama dan yang menjadi pelaku utama adalah masyarakat itu sendiri, yakni nelayan. Dengan demikian, potensi manusia juga sejatinya harus diposisikan sama dengan potensi fisik wilayah dan juga menjadi penentu dari keberhasilan pembangunan maritim.

Berdasarkan pandangan tersebut, salah satu potensi yang dapat mendorong perubahan pulau kecil ke arah yang lebih baik adalah potensi sistem sosial masyarakat. Konteks ini dimaksudkan dalam ikatan atau hubungan manusia dengan manusia lainnya, hubungan manusia dengan sumberdaya alamnya, serta hubungan 
manusia dengan alam metafisik sebagai sistem sosial dan sistem budaya pulau kecil yang terbangun.

Berdasarkan sudut pandang antropologis, pendekatan dalam memahami perilaku serta eksistensi suatu masyarakat dapat dilihat dan bertitik tolak serta berorientasi pada hasil dari hubungan dialektika antara interaksi manusia, lingkungan, dan kebudayaannya. Oleh karena itu, dalam berbagai kondisi lingkungan yang melingkupi tata cara hidup manusia, satuan sosial, serta interaksi yang terjadi di dalamnya sebagai sebuah proses akan menampilkan ciri khas atau karakteristik budaya yang berbeda-beda antara satu wilayah dengan budaya wilayah lainnya (Susanti \& Lestari, 2020). Dengan demikian, tata cara kehidupan serta perilaku yang diadaptasi oleh masyarakat nelayan di Pulau Kambuno sebagai hasil interaksi dengan alam lingkungannya tentu saja memiliki ciri khas yang spesifik sebagai pembeda dengan wilayah lain, termasuk wilayah di daratan pesisir.

Konteks kebudayaan di Sulawesi Selatan, Nurhayati \& Nurkholik (2018), menjelaskan bahwa histori pertumbuhan budaya dan adatnya semakin kuat setelah agama Islam masuk dan diterima sebagai agama resmi kerajaan yang diikuti oleh sebagian besar masyarakat Sulawesi Selatan. Konsep pangadereng (adat) sebelum masuknya agama Islam hanya meliputi empat unsur, yaitu ade (sistem norma dan aturan), bicara (reaksi terhadap tindakan yang melanggar adat), rapang (perumpamaan) dan wari (azas membedakan) kemudian ditambahkan menjadi lima unsur adat, yaitu sara (hukum atau aturan-aturan agama). Di antara berbagai aturan adat yang masih berlaku maupun yang tidak berlaku, sebagian berbentuk tertulis yang tersebar dalam berbagai lontar, sebagian lagi tidak dalam bentuk tertulis (lisan) yang diturunkan atau diwariskan dari satu generasi ke generasi selanjutnya melalui pappaseng (pesanpesan), atau pappangaja (petuah-petuah) serta gaukang (berupa tindakan-tindakan) yang kesemuanya mengandung makna kontesktual dalam kehidupan sehari-hari dan dijadikan sebagai pedoman hidup dan bertingkah laku.

Salah satu ade' (sistem norma dan aturan) sebagai sistem tradisi yang terwarisi dalam aktivitas kehidupan masyarakat nelayan di Sulawesi Selatan, termasuk nelayan di Pulau Kambuno adalah aturanaturan mengenai pelayaran dan kenelayanan yang dikenal dengan istilah ade' allopilopinge atau ade' assompereng. Adat tradisi ini mengatur tentang berbagai hal yang menyangkut dengan tata cara aktivitas pelayaran yang didalamnya terdapat aturanaturan untuk menjaga keselamatan para nelayan atau para pelayar di lautan, serta tata cara melihat simbol-simbol alam kaitannya dengan sumberdaya perikanan. Arief (2007) menjelaskan bahwa tingkah laku manusia dalam kelompok atau dalam sistem sosial pada umumnya ditentukan oleh unsur-unsur sistem budaya, yaitu nilai-nilai (values), norma-norma (norms), pengetahuan (knowledge), teknologi (technology), kepercayaan (belief), dan simbolisasi (simbolization) yang berpenetrasi (menembus) ke dalam sistem sosial masyarakat.

Dengan demikian, dapat diasumsikan bahwa pengetahuan nelayan di Pulau Kambuno terkait dengan kepercayaan dan pamali dalam hal penangkapan ikan merupakan praktik tradisi yang terwarisi dengan memanfaatkan alam metafisik sebagai lingkungan dari sistem kehidupannya dan menjadi tata kelakukan yang beroperasi dan mengatur interaksi manusia dalam menjalankan aktivitasnya sebagai nelayan. Pamali yang diyakini dapat dikategorikan sebagai wujud kearifan lokal karena pamali tercipta dan dihasilkan dari pengetahuan suatu kelompok masyarakat. Hal ini dapat diartikan bahwa segala informasi yang tersampaikan, baik yang tertulis ataupun lisan, dari generasi sebelumnya akan berbagai pantangan atau hal yang menyangkut larangan, sesungguhnya adalah kata-kata kearifan yang mengandung kearifan lokal (Sarmidi, 
2015). Isnendes (2014) menjelaskan bahwa kearifan lokal bersifat abstrak dan konkret, sistem abstrak, sedangkan dalam praktiknya adalah sistem konkret. Hal tersebut sesuai dengan pendapat Selasih \& Sudarsana (2018) bahwa kearifan lokal adalah proses pengetahuan yang dihasilkan, disimpan, digunakan, diolah, dan diwariskan. Kearifan lokal dijadikan pedoman bagi kehidupan masyarakat karena memiliki nilai-nilai edukatif yang disampaikan secara tidak langsung, seperti pamali. Pamali menjadi salah satu tanda perilaku masyarakat dalam mengelola alam untuk memberikan manfaat yang sejahtera bagi masyarakat (Nurdiansah, 2017).

Berdasarkan hal itu, tujuan penelitian ini adalah untuk menganalisis kepercayaan dan pamali nelayan pulau kecil (Pulau Kambuno) sebagai tata kelakuan dalam aktivitas nelayan yang dipengaruhi oleh unsur-unsur budaya lokal yang telah berpenetrasi (menembus) ke dalam sistem sosial masyarakat. Penelitian ini dapat bermanfaat dalam rangka pengembangan dan perubahan nelayan pulau kecil ke arah yang lebih sesuai dengan tuntutan pembangunan perikanan atau modernisasi, khususnya perubahan tingkah laku dalam mengelola usaha perikanan tangkap menjadi lebih efisien dan lebih efektif sesuai dengan tuntutan perubahan zaman.

\section{Metode}

Penelitian dilakukan di Pulau Kambuno Kabupaten Sinjai Sulawesi Selatan pada bulan February-Mei 2020. Lokasi dipilih secara sengaja (purpossive) atas dasar pertimbangan kriteria bahwa di pulau ini mayoritas penduduknya adalah nelayan yang masih mengandalkan pengetahuan lokal dalam menjalankan aktivitasnya sebagai nelayan. Pendekatan penelitian adalah kualitatif dengan jenis studi kasus. Penentuan metode berdasarkan apa yang dikonsepkan oleh Babbie (2004) bahwa pada umumnya penelitian sosial dilakukan dengan pendalaman studi kasus yang fokus perhatiannya pada satu atau beberapa contoh fenomena sosial, seperti keluarga, mata pencaharian dan desa. Penelitian ini mendalami fenomena kepercayaan dan pamali sebagai norma-norma sosial yang beroperasi dan mengatur interaksi mereka dalam menjalankan aktivitas mata pencahariannya. Pengumpulan data dilakukan melalui pengamatan langsung serta wawancara mendalam dengan sejumlah informan tentang kepercayaan dan pamali yang dijadikan sebagai tata cara yang didalamnya terdapat berbagai aturan-aturan yang harus dipraktikkan sebagai nelayan.

Berdasarkan proses ini, didapatkan suatu deskripsi komprehensif mengenai tindakan dan praktik dalam menjalankan aktivitas sebagai nelayan. Selama penelitian ini berlangsung, dijumpai sebanyak 30 informan sebagai sumber data primer. Pengumpulan data sekunder melalui studi pustaka. Penggalian informasi data primer menyangkut pengetahuan lokal, teknologi budidaya, serta kepercayaan yang diyakini dalam menjalakan usaha. Wawancara mendalam kepada key informant juga dilakukan kepada penduduk yang dianggap memahami permasalahan penelitian. Adapun orang-orang yang dijadikan sebagai informan kunci adalah tokoh nelayan, tokoh masyarakat, tokoh adat, punggawa, dan sawi.

Data kepercayaan dan pamali nelayan kemudian dianalisis melalui content analysis dari kompilasi hasil wawancara melalui teknik snowball dengan tetap mengacu pada prinsip triangulasi (Miles, M.B, Huberman, A.M, dan Saldana, 2014) melalui tiga tahap: tahap pertama, analisis data kualitatif yang dilakukan adalah proses reduksi data kasar dari catatan lapangan. Pada prosesnya, dipilih data yang relevan dengan fokus penelitian dan data yang tidak memenuhi kriteria eksklusifinklusif. Tahap kedua, penyajian data merupakan penyusunan sekumpulan informasi menjadi pernyataan yang memungkinkan penarikan kesimpulan. Data disajikan dalam bentuk teks naratif, mulanya terpencar dan terpisah pada berbagai sumber informasi, kemudian diklasifikasikan menurut tema dan 
kebutuhan analisis. Tahap ketiga, penarikan kesimpulan berdasarkan reduksi dan penyajian data. Penarikan kesimpulan berlangsung bertahap dari kesimpulan umum pada tahap reduksi data, kemudian menjadi lebih spesifik pada tahap penyajian data, dan lebih spesifik lagi pada tahap penarikan kesimpulan yang sebenarnya. Rangkaian proses ini menunjukkan bahwa analisis data kualitatif dalam penelitian ini bersifat menggabungkan tahap reduksi data, penyajian data, dan penarikan kesimpulan secara berulang dan bersiklus.

\section{Hasil dan Pembahasan}

\subsection{Profil Pulau Kambuno}

Pulau Kambuno adalah salah satu pulau dari sembilan pulau yang ada di kawasan Pulau-pulau Sembilan Kabupaten Sinjai. uas sekitar $0,17 \mathrm{~km}^{2}$ dengan tinggi tanah dari permukaan laut sekitar 1 meter. Wilayah permukiman secara keseluruhan mempunyai luas sekitar $0,21 \mathrm{~km}^{2}$. Keadaan topografinya adalah $75 \%$ daratan dan $25 \%$ berbukit. Dikenal dua musim di pulau ini, yaitu musim kering atau kemarau dan musim basah atau hujan. Musim kemarau terjadi pada Oktober hingga Januari, sedangkan musim hujan terjadi pada Juni hingga September dan musim peralihan pada bulan Februari hingga Mei. Nelayan di Pulau Kambuno membagi tiga pola musim yang sangat mendukung aktivitasnya sebagai nelayan. Berdasarkan pengetahuan dan pengalaman nelayan, mereka mengetahui waktu-waktu yang intensif dan waktu yang dianggap sepi untuk melakukan kegiatan penangkapan ikan. Adapun waktu tersebut, yaitu musim timur, musim pancaroba, dan musim barat. Musim timur terjadi antara bulan Desember hingga Juni ditandai dengan angin dan arus agak lemah dari timur ke barat sehingga menjadi peluang besar bagi nelayan di pulau ini dan pelayaran rakyat beroperasi secara intensif. Sementara memasuki bulan Juli sampai bulan Desember terjadi musim barat dengan kondisi hujan yang lebat, angin yang bertiup kencang dan sering disertai dengan badai besar dan arus kuat dari arah barat ke timur. Kondisi cuaca seperti ini menjadikan nelayan kurang memungkinkan mereka melakukan aktivitas menangkap ikan dan pelayaran rakyat. Musim peralihan terjadi kurang lebih tiga bulan, yakni Mei-Juli. Pada musim peralihan, kondisi angin serta goncangan ombak kurang menentu dan terjadi terus-menerus. Selama terjadinya musim peralihan di perairan terbuka di Indonesia Bagian Timur, termasuk Sulawesi Selatan, kecuali sebagian kecil Teluk Bone, sulit diakses selama musim peralihan tersebut. Oleh karena itu, mata pencaharian alternatif sangat dibutuhkan oleh penduduk di pulau ini dalam mengantisipasi musim yang menghalangi akivitas produksi mereka sebagai nelayan untuk tetap dapat berpenghasilan. Menurut (Jumardi et al., 2018), mata pencaharian alternatif yang dapat dilakukan dan dikembangkan oleh nelayan pulau kecil dalam meningkatkan pendapatan ekonomi keluarga adalah pengolahan hasil perikanan seperti abon ikan, kerupuk ikan, budidaya rumput laut dan budidaya keramba jaring apung. Pekerjaan alternatif ini sekaligus menjadi solusi dalam mengatasi aktivitas sebagai nelayan yang terhenti akibat musim paceklik.

Pada 2018, jumlah penduduk di pulau ini sebanyak 2524 jiwa, terdiri atas penduduk pria 1240 jiwa dan penduduk wanita sebanyak 1284 jiwa. Didominasi suku Bugis dan Bajo. Kondisi permukiman bertipe menyebar di empat sudut pulau yang ditandai oleh dua buah dermaga penyeberangan. Tempat tinggal didirikan pada posisi di atas hamparan tanah datar, sedangkan yang ada diperbukitan menyesuaikan dan mencari tempat yang tepat untuk mendirikan rumah. Pekerjaan pokok penduduk pulau adalah nelayan dan sebagian lainnya beraktivitas di bidang perikanan lainnya juga seperti budidaya rumput laut, pedagang hasil-hasil perikanan dan sebagainya. Dermaga penyeberangan terletak di dusun Kambuno Timur dan satunya lagi di dusun Kambuno Barat. Jalan yang menghubungkan dari satu tempat ke 
tempat lainnya berupa jalan setapak yang kondisinya sebagian besar telah disemen beton dan selebihnya berupa jalan tanah. Infrakstuktur yang menunjang atau mendukung perekonomian di pulau ini masih tergolong sangat minim. Untuk menghubungkan antara satu dusun dengan dusun lainnya, terdapat jalan tanah dengan lebar kurang lebih 1 meter. Jalan tanah tersebut merupakan jalan desa dan jalan dusun. Karena luas wilayah yang hanya sekitar $0,21 \mathrm{~km}^{2}$, sistem transportasi darat tidak terlalu penting sehingga untuk kegiatan bepergian antar dusun dilakukan dengan berjalan kaki. Interaksi antarpulau dengan pulau lainnya mereka menggunakan perahu jolloro, katinting, atau perahu bise. Satusatunya sarana transportasi ke dan dari Pulau Kambuno menggunakan sarana angkutan laut berupa kapal motor yang beroperasi dengan jadwal tertentu tiap harinya (berangkat dari Pulau Kambuno ke TPI Lappa sekitar pukul 06.30 wita dan kembali sekitar pukul 13.00 wita), kecuali untuk perahu motor tempel/ katinting dan jonson (speed boat) pengoperasiannya dapat terjadi setiap saat dengan sistim sewa carteran di TPI Lappa. Konteks ini memperlihatkan bahwa aksesibilitas masyarakat pulau kecil adalah kebutuhan yang sangat esensial dalam rangka mendukung interaksi sosial ekonomi mereka, baik antar pulau kecil maupun dengan pulau induknya. Oleh karena itu, sarana trasportasi laut yang reguler harus diperbanyak di pulau-pulau kecil agar kebutuhan akan aksesibilitas tersebut dapat terlayani dengan baik. Konteks ini sejalan dengan apa yang dikatakan Subagiyo et al., (2017) bahwa salah satu syarat utama mendorong perkembangan ekonomi di pulau-pulau kecil khususnya pengembangan wisata bahari adalah ketersediaan sarana trasportasi laut yang memadai untuk kepentingan wisatawan dan kelancaran aksesibilitas penduduk pulau-pulau kecil dalam aktivitas sosial ekonominya.

\subsection{Kepercayaan Nelayan Pulau}

Pengetahuan yang dimiliki masyarakat nelayan di Pulau Kambuno dalam hal penangkapan ikan berkaitan erat dengan kepercayaan, khususnya kepercayaankepercayaan berdasarkan adat kebiasaan dan menjadi tata kelakuan dalam menjalankan aktivitas sebagai nelayan. Kepercayaan yang berdasarkan adat kebiasaan ini merupakan salah satu sumber atau latar belakang dari pada norma-norma sosial yan beroperasi dan mengatur interaksi nelayan, baik interaksinya dengan sesama nelayan, dengan alam fisik, maupun dengan Sang Pencipta melalui simbol-simbol alam. Adapun kepercayaan-kepercayaan yang dijadikan pedoman bagi nelayan di pulau ini adalah sebagai berikut.

\subsubsection{Kepercayaan terhadap Hari Baik dan Hari Buruk}

Nelayan di Pulau Kambuno pada umumnya masih sangat meyakini pada pengetahuan yang diwarisinya (local knowledge) yang dilandasi oleh basis kepercayaan mengenai hari yang diyakini sebagai hari baik dan hari tidak baik (buruk) dalam memulai aktivitas pekerjaan, khususnya membeli atau menggunakan peralatan-peralatan baru yang akan dipergunakan dalam kegiatan menangkap ikan. Perhitungan mengenai hari baik dan hari buruk sangat diyakini dalam hal keselamatan dan perolehan rezeki. Berikut penuturan informan (HBD, 65 tahun) kepada peneliti berikut.

"aja mucapai riasengge esso madeceng sibawa esso makonja, nasaba ancajinna esso engka maneng assalengna, iyanatu engka pakkaja bale madeceng dallena sibawa etuo-tuona nasaba naissengngi esso madecengnge napammulai jamajamanna"

Terjemahan:

"Jangan menganggap remeh yang namanya hari baik dengan hari buruk, sebab proses lahirnya semua hari ada dasarnya, itulah sebabnya ada nelayan yang baik rejekinya dan baik kehidupannya karena dia paham 
mengenai hari baik untuk memulai pekerjaanya," (wawancara tanggal 12 Februari 2020).

Adapun hari-hari yang baik menurut kebiasaan nelayan untuk memulai suatu pekerjaan atau membeli peralatan produksi adalah Minggu, Senin, Rabu dan Jumat. Di sisi lain, hari yang dianggap tidak baik untuk memulai suatu pekerjaan atau membeli peralatan produksi bahkan dianggap akan membawa nasib sial adalah hari Sabtu, Selasa dan hari Kamis. Dengan demikian, perhitungan mengenai hari baik dan buruk dalam seminggu terdapat empat hari baik dan tiga hari yang tidak baik atau buruk. Diperoleh keterangan dalam penelitian bahwa alasan dipilih hari Rabu sebagai hari baik untuk memulai suatu pekerjaan atau membeli dan mengoperasikan peralatan produksi baru karena hari tersebut menurut perhitungan tahun Qamariah terjadi pada Rabu Syafar.

Menurut Ibrahim (2018), sampai saat ini, salah satu pedoman hari-hari yang dikatakan baik dan dijadikan tuntunan oleh nelayan pulau-pulau kecil di Sulawesi Selatan dalam melakukan kegiatan sebagai akivitas keseharian adalah perhitungan mengenai pokok tahun berdasarkan kepercayaan Agama Islam, yakni 1 Muharram sebagai perhitungan dalam delapan tahun yang terpahami dengan istilah satu pariama. Konteks ini juga dapat dijadikan salah satu penjelas bahwa secara historis dikalangan masyarakat Islam di Indonesia juga sering dijumpai kecenderungan terhadap segi-segi mistik Islam.

\subsubsection{Kepercayaan terhadap Ilmu Gaib}

Tampak bahwa lapangan pencaharian hidup sebagai nelayan amat menantangnya untuk mempercayai kekuatan-kekuatan gaib. Mengarungi laut dalam pandangan nelayan adalah sebuah misteri yang fenomenanya terkadang tidak dapat dirasionalkan. Mereka selama berada di lautan merasa sedang mempertaruhkan jiwa raga dalam mendapatkan rejeki yang disediakan Tuhan untuknya. Menurut informan, laut kadang tenang penuh dengan "persahabatan" tetapi tiba-tiba bisa secepat itu berubah dengan ombak yang sangat tinggi seakan penuh "amarah". Pada waktu yang lain, mereka juga terkadang menjumpai ikan-ikan yang sangat besar dan dapat menenggelamkan perahu. Begitu pula pengalaman yang diceritakan terkait dengan antulau (hantu laut), makhluk aneh yang mereka jumpai selama dalam perjalanan menangkap ikan. Oleh karena itu, seorang punggawa laut (pemimpin kegiatan produksi di laut; nahkoda) di samping memiliki pengalaman tentang perahu dan pelayaran, juga harus memahami ilmu gaib yang dapat menolak bahaya untuk keselamatan selama menangkap ikan.

Adapun ilmu gaib yang digunakan atau sering digunakan oleh nelayan di pulau ini dan dikenal dengan istilah sebagai berikut.

a) Ilmu mabbinru adalah suatu gaukang (tingkah laku) dengan memegang ujung perahu yang disertai dengan membaca mantera-mantera yang dilakukan oleh punggawa laut, lalu mengitari perahunya sebanyak tiga kali sebelum berangkat.

b) Ilmu tapakkorok adalah duduk di pusat rumah sebelum berangkat menenangkan pikiran atau hati sambil menunggu ucapan yang baik dari penghuni rumah (keluarga) yang mengandung arti keselamatan, seperti kata-kata salamak (selamat), madeceng (baik) dan sebagainya.

c) Ilmu ammolong laso anging adalah ilmu yang dapat mematahkan laso anging (angin tornado) yang datang menyerang perahu.

d) Ilmu mappapeca batu adalah suatu ilmu yang dapat melembekkan atau mencairkan batu karang pada situasi atau kondisi perahu terpaksa harus melintasinya.

Di samping itu, ilmu gaib juga diasosiasikan dengan motif memperoleh rezeki atau memperoleh hasil tangkapan ikan yang banyak. Laut bagi mereka adalah tantangan yang tidak mudah untuk 
ditaklukkan. Nelayan adalah pemburu ikan yang tidak pasti keberadaannya sehingga keberhasilannya memperoleh tangkapan ikan yang banyak selalu digantungkan dengan banyaknya ikhtiar yang mereka lakukan. Menurut informan, sering terjadi bahwa nelayan pergi melaut terkadang tidak memperoleh hasil tangkapan seekor pun untuk mereka jual. Akan tetapi, kadangkadang pula tampa harus berlama-lama di laut tiba-tiba banyak ikan cakalang besar yang dapat mereka tangkap. Menurut mereka, segala sesuatunya mengenai rejeki di laut pasti ada penyebabnya, misalnya kurangnya tangkapan karena perahu atau jala sudah terlalu lama tidak diselamati dengan ritual barasanji atau baca salawat. Jadi, intropeksi diri mereka lakukan sampai memperoleh pemecahaannya.

Berikut penuturan informan (BHN, 62 tahun) tentang pengalamannya yang berkaitan dengan ilmu gaib yang dimilikinya sewaktu akan menggiring ikan masuk ke dalam jaring dengan mengucapkan kalimat sebagai berikut.

"lanraci asemmu uwwae, nabimu nabi helere, nabimu iko balewe nabi daude, lokkanomai maddeppungeng, Nurung parentako, Muhammad terimako; Alla Taala makkudalle riko; Kumpayakung" Terjemahan : "wahai air namamu lanraci, nabimu Nabi Helere, nabimu wahai ikan Nabi Daude, kesinilah berkumpul; Nurung yang memerintahkanmu, kamu diterima Muhammad; rejekimu Allah Taala yang berikan; jadilah'(wawancara tanggal 20 Februari 2020).

Dapat disimpulkan bahwa seringkali secara magis atau perilaku secara magis yang dipraktikkan oleh nelayan di pulau ini, tampak sebagai usaha dalam memanggil, memobiilsasikan dan memanipulasi energi yang ada di alam metafisik sebagai interaksi yang dilakukan sehingga magis dianggap memiliki fungsi yang seolah-olah menyerupai cara kerja dari teknologi penangkapan yang sifatnya modern. Konteks ini membuktikan bahwa kedekatan hubungan manusia dengan lingkungan sumberdaya alamnya adalah kondisi riil yang tidak dapat terbantahkan. Dapat dipastikan bahwa tanda-tanda serta ciri-ciri dari alam terpahami dan dipelajari sebagai sebuah pengalaman yang berulang-ulang oleh kelompok tersebut. Bagi masyarakat nelayan tradisional, berbagai tanda-tanda yang muncul baik dari alam metafisik maupun dari alam fisik. Semuanya harus termaknai sebagai hubungan persuasif dalam menjaga keselarasan atau harmonisasi antara manusia dengan alam sehingga berbagai bentuk ritual, magis, dan tradisi telah menjadi media komunikasi dalam interaksi hubungan tersebut (Taufiq, 2018).

\subsubsection{Kepercayaan Berdasarkan Tanda- Tanda Alam}

Pemaknaan tanda-tanda alam merupakan pengetahuan yang bersumber dari kepercayaan berdasarkan pengalaman empiris yang diwariskan dari generasi ke generasi. Pengetahuan lokal ini dijadikan acuan dalam melihat sekaligus menafsirkan setiap kali beraktivitas, termasuk menentukan arah ke mana nelayan mencari lokasi yang tepat untuk melakukan aktivitas penangkapan ikan. Menurut informan, bilamana mereka dalam beraktivitas tidak mengacu pada pengetahuan lokal yang mereka miliki, maka dirasakannya sebagai pekerjaan yang sia-sia. Sebaliknya, mereka sadar betul bahwa ketika yang dijadikan patokan dalam beraktivitas itu terpenuhi, maka mereka betul-betul merasa puas. Pengetahuan yang mereka miliki merupakan model dan bentuk pengetahuan yang tidak terikat pada pengetahuan yang bisa dianalogikan, pengetahuan yang telah teruji dari pengalaman dan terwariskan dari satu generasi ke generasi berikutnya, sehingga ketika meleset dari kondisi riil, maka semua disikapi sebagai musibah. Adapun tandatanda alam yang dimaknai oleh nelayan sehubungan dengan aktivitasnya dalam melakukan penangkapan ikan, adalah sebagai berikut.

a) Anging Tinoro adalah kondisi angin yang bertiup dan terjadi sekitar Juli dan 
Agustus. Bertiupnya berkepanjangan, biasanya sekali-kali agak kencang. Fenomena ini didahului dengan tandatanda alam yang diamati oleh nelayan, seperti air sedang pasang dan angin berhembus sedikit keras dan pada waktu malam bintang-bintang di langit kelihatan cahayanya kurang terang (redup).

b) Anging Barak adalah kondisi angin yang bertiup yang berasal dari Barat Daya serta Barat Laut. Tanda-tanda alam yang diamati oleh nelayan sebagai berikut. 1) Air laut dalam keadaan tenang sekali, mulai malam hari sampai siang hari, dan angin ini nampak mulai bertiup pada kondisi sore hari sampai waktu malam. 2) Cuaca gelap atau menghitam di sebelah Barat. 3) Didahului oleh kilat yang sedatar air dengan air laut atau biasa juga kilat tersebut berdiri menjulang ke atas. 4) Pada saat hujan sedang turun disertai dengan bunyi guntur.

c) Anging Barubu adalah angin yang bertiup panas dan kering dan datang melalui sela-sela gunung. Angin Barubu ini bertiup tidak menetap arahnya, kirakira bertiup pada Juli sebagai angin Timur Laut yang panas dan kering. Bertiupnya pada tengah hari dan baru berhenti menjelang terbenamnya matahari.

d) Laso Anging (Pusat Angin), yakni kondisi ketika angin datang berputar sangat kencang dan sering terjadi pada musim barat. Biasanya nelayan mengatasi dengan cara telanjang bulat di atas perahu atau menghunus badi lalu mengayunkan ke udara sebanyak tiga kali, maka angin tersebut akan bergerak menjauhi kapal yang tengah melakukan pelayaran.

e) Keberadaan batu karang tanda-tanda yang diamati 1) Pada waktu malam, keberadaan batu karang ditandai adanya kilat menggores di atas permukaan air yang berbatu tersebut. 2) Pada waktu terang bulan, air laut air laut mengkilatkilat akibat pantulan cahaya. 3) Pada waktu siang hari, air laut berwarna putih akibat pecahan ombak di atasnya. 4) Berbau anyir, baunya dapat dirasakan/dicium kira-kira satu mil sebelum batu karang tersebut ada.

f) Tanda-tanda alam melalui ombak, yaitu manakala ada riak-riak kecil di antara gelombang-gelombang, maka disitulah mereka memasang peralatan yang ia gunakan untuk menangkap ikan. Ombak dapat membawa berita kepada nelayan melalui benda-benda yang terbawa arus ombak. Misalnya seorang nelayan yang sementara berdiri di pantai sebelum berangkat, tiba-tiba ia melihat sebuah benda (minimal $17 \mathrm{~kg}$ beratnya), yang terbawa ombak tetapi sebelum sampai di pantai, air surut kembali, hal ini menurut beberapa nelayan merupakan kabar gembira.

g) Tanda-tanda alam melalui bintang sebagai berikut. 1) Tallu-tallua adalah bintang dengan jumlah tiga buah, posisi berjejer lurus dari bagian utara ke bagian selatan, bintang ini dijadikan sebagai pedoman dan penunjuk arah dalam pelayaran.2) Purung-purung adalah bintang yang berjumlah enam buah yang muncul di sebelah timur dan terbitnya sekitar pukul 04.00 subuh dan tenggelam pada pukul 06.00 pagi. Kapan purung-purung bergeser ke barat itu artinya memasuki musim barat atau musim hujan. Jika purung-purung menghadap ke timur, maka nelayan sangat antusias melihat tanda-tanda tersebut karena di situlah terdapat banyak ikan. 3) Balua ialah bintang yang dilihat di sebelah selatan. Kemunculan bintang ini dijadikan penanda oleh nelayan bahwa akan datang segerombolan ikan yang menampakkan dirinya di permukaan laut, khususnya ikan torani (ikan terbang). 4) Buntalak adalah bintang yang berbentuk buntalak (sejenis ikan berduri yang bisa membesar perutnya apabila merasa terancam). Bintang ini juga berada di sebelah selatan. Bila muncul bintang buntalak, maka 
dijadikan penanda oleh nelayan bahwa

ikan terbang telah mengeluarkan telurnya di laut.

Dapat disimpulkan bahwa pengetahuan tradisional (tanda-tanda alam) yang dijadikan pedoman oleh nelayan dalam menjalankan aktivitasnya bersumber dari pengalaman yang dirasakan dan diceritakan sebagai pengetahuan yang diwarisi dan diyakini kebenarannya dalam mengarungi lautan sebagai penangkap ikan.

Konteks ini juga menjelaskan bahwa masyarakat nelayan di Pulau Kambuno sampai saat ini memiliki cara berpikir (way of thinking) yang melahirkan suatu tindakan perilaku sebagai reaksi adaptasi manusia (nelayan) terhadap sumberdaya alamnya adalah cara berpikir totalitas (the totalitarian way of thinking). Cara berpikir totalitas adalah cara berpikir yang menganggap bahwa segala sesuatu yang ada di kosmos merupakan hasil hubungan secara organis sehingga tidak dapat dipisah-pisahkan satu dengan yang lainnya. Manusia memandang dirinya sebagai bagian dari alam atau kosmos atau merupakan mikrokosmos dari makrokosmos. Dengan demikian, rumahnya, perahunya, lautnya bahkan pulaunya adalah masing-masing mikrokosmos dari makrokosmos, sedangkan adatnya merupakan tata tertib yang harus sesuai dengan tata tertib makro-kosmos.

Oleh karena itu, di dalam kosmos tidak boleh ada pertentangan yang mutlak, semuanya harus serasi satu sama lain atau harmonis. Nelayan pulau ini memandang dirinya bersama alam dengan berbagai aspeknya, berada dalam satu sistem, yaitu sistem kehidupan (mikro kosmos bagian dari makro kosmos), yang mereka pandang sebagai lingkungan dari sistem tersebut adalah alam metafisik. Alam metafisik sebagai lingkungan dari sistem kehidupan kemudian diadaptasikan dalam rangka interaksi. Oleh karena itu, pada masyarakat tradisional pengetahuan-pengetahuan yang mereka miliki berkaitan erat dengan mitos, kultus, ritus, dan magis. Sehingga di dalam kehidupan sehari-harinya berkenaan dengan interaksi, termasuk interaksinya dengan sumberdaya alam (alam fisik) banyak dijumpai perilaku ritual dan magis. Menurut Lampe (2012), dalam kerangka penguatan eksistensi nelayan maka diperlukan pemahaman baru berupa sinergitas unsurunsur pengetahuan lokal dan pengetahuan ilmiah (the objectivating way of thinking) serta mendorong kreativitas nelayan. Hal ini dimaksudkan agar aktivitas produksi nelayan dapat memberikan konstribusi berupa pencapaian hasil yang optimal dan berkualitas sebagai wujud perubahan ke arah yang lebih efektif dan efisien.

\subsection{Pamali Nelayan}

Berbagai kegiatan ritual yang masih dilakukan, baik secara perorangan maupun berkelompok oleh masyarakat tradisional, dimaknai sebagai penanda bahwa mereka masih menjunjung tinggi dari tradisi kebudayaan yang terwarisi secara turuntemurun. Gambaran corak tradisi serta budaya khas tersebut ditampilkan dalam dimensi wujud dan dimensi isi. Kekhasan budayanya dapat diamati dalam berbagai praktek tradisi lisan. Salah satu tradisi lisan sebagai warisan leluhurnya yang masih tetap diperthankan dalam aktivitas kesehariannya dalam mencari ikan adalah pamali. Dalam kajian sastra lisan, pamali berhubungan dengan ungkapan, yaitu ungkapan berupa larangan atau ungkapan berupa pantangan (Aisyah, 2020). Praktik pamali lazimnya berupa ungkapan yang termaknai dengan kata jangan atau tidak boleh yang berpola sebagai sebab akibat.

Pamali yang ditemukan dalam penelitian ini adalah berupa pantangan yang tidak boleh dilakukan demi keselematan dalam menjalankan aktivitas sebagai nelayan dan juga termasuk mendapatkan rejeki (hasil tangkapan ikan yang banyak). Hasil wawancara dengan informan (USM, 71 tahun; tokoh nelayan) diperoleh keterangan bahwa selama dalam perjalanan mencari daerah tangkapan para anggota kelompok kerja di atas perahu dipantangkan untuk bersusah hati, keadaan perahu harus selalu bergembira untuk menyambut ikanikan yang ada di laut agar mendekat ke 
perahunya. Selanjutnya, juga dikatakan bahwa dipantangkan kentut, bersin, dan menguap selagi memasang jala. Menggunjingkan orang lain atau menyatakan kekecewaan atau kedengkian kepada siapapun. Seluruh anggota kelompok (sawi) dipantangkan untuk memakai kata-kata ingkar seperti de'gaga (tidak ada) dan sedapat mungkin kata tersebut dicarikan padan kata dengan makna yang tetap sama seperti masempo (murah).

Pantangan lainnya ialah menyebut nama-nama binatang tertentu seperti jonga (rusa), bawi (babi), tedong (kerbau), asu (anjing) dan sebagainya selama dalam perjalanan. Kalau terpaksa harus menyebutkan hal itu, maka harus disamarkan dengan mencari ciri-ciri fisik dari hewan yang dimaksud untuk disebutkan, seperti lampe ellong (si panjang leher) untuk hewan rusa, muruk untuk hewab babi, tamboh untuk hewan kerbau serta gonggong untuk hewan anjing.

Berikut penuturan informan (DLA, 65 tahun) yang menceritakan pengalamannya yang berkaitan dengan pamali sebagai berikut .

"ko de diappamali, abiasanna compai abalae, biasanya mammula compa bale mancaji maliai, jalae tasakkai di batu karange, tappa biasa to compai bale lompoe pada launa mangamuk elo natongkang lopie"

Terjemahan: "Kalau pantangan ini tidak diindahkan, maka akan muncul bahaya yang diawali perilaku ikan yang sangat liar, alat tangkap jala terantuk batu karang dan sering pula tiba-tiba muncul ikan besar yang mengamuk dan berusaha membalikkan perahu" (wawancara tanggal 25 Februari 2020).

Semua pantangan itu dikenal dan dipercayai oleh punggawa (pemimpin kegiatan penangkapan ikan di laut) dan sawi (anak buah atau anggota kelompok kerja). Hal tersebut merupakan aturan tambahan yang harus dipenuhi setiap kali dalam melakukan kegiatan penangkapan ikan.
Nilai yang menjadi pedoman nelayan di pulau ini dikenal dengan istilah "koimitu di nyamengnge napoleki dalle". Artinya, "pada suasana keriangan hatilah kita kedatangan rejeki”. Oleh karena itu, menggunjinkan orang, takabur, kentut, bersin, dan menguap dapat mempengaruhi jiwa menjadi kurang riang atau susah sama sekali. Begitu juga dengan kata-kata ingkar "degaga" (tidak ada) dapat membawa suasana hati tidak optimis menanti datangnya rejeki.

Di samping pantangan-pantangan yang harus dijalankan oleh anggota kelompok kerja di perahu penangkapan ikan, beberapa pantangan juga harus diakukan oleh anggota keluarga para nelayan, baik pada saat suamisuami mereka akan berangkat meninggalkan rumah juga pada saat nelayan ada tengah laut. Adapun pantangan yang harus dipatuhi bagi anggota keluarga nelayan dirumah pada saat nelayan ada di tengah laut adalah sebagai berikut.

a) dipantangkan menurunkan barangbarang perabot rumah tangga di waktu malam

b) dipantangkan mencuci/menjemur kelambu, bantal, dan kasur

c) dipantangkan memperbaiki bagian rumah seperti dinding rumah, atap,dan lain-lain

d) dipantangkan menyapu di waktu malam

e) dipantangkan mencukur rambut atau memotong kuku selama nelayan ada di tengah laut.

Makna dari pamali di atas ialah mengingatkan para istri agar selalu berhatihati dan fokus dalam merawat anaknya. Jika banyak hal-hal yang dikerjakan sepeninggal suami mereka, bisa saja terjadi sesuatu yang tidak terduga dan sebaiknya si ibu harus selalu memperhatikan hal-hal yang ada di dalam rumah, khususnya yang berkaitan dengan keselamatan anak-anaknya.

Dapat disimpulkan bahwa makna sesungguhnya dari pamali tidak hanya makna tekstual (hal yang dipantang atau dilarang itu) melainkan ada makna kontekstualnya (tersirat di balik teks pantang larang itu) (Komalasari, 2018). Semua 
pamali yang ada dalam komunitas, masyarakat memiliki makna terdalam yang sesungguhnya melebihi makna tekstual saja, sehingga makna tersebut harus dapat diinterpretasikan dalam alam pikiran rasional sebagai substansi dari komunikasi pantangan yang sesungguhnya banyak mengandung bimbingan dan tuntunan hidup. Dalam hal pemanfaataan sumberdaya perikanan, praktik pamali yang diyakini oleh masyarakat nelayan pulau ini merupakan gambaran bahwa sumberdaya alam tersebut tidak hanya direduksi untuk kepetingan ekonomi semata, tetapi juga sumberdaya alam tersebut juga diperuntukkan untuk kepentingan ekologi, sosial dan budaya. Pamali juga berfungsi sebagai barikade sosial untuk tidak terjadinya dehumanisasi dan deekologis. Menurut Alains et al., (2009), salah satu modal dasar dalam pengelolaan sumberdaya perikanan berbasis masyarakat adalah adanya kepercayaan berupa pantangan-pantangan yang tidak boleh dilakukan dalam eksploitasi sumberdaya yang tetap dipertahankan oleh komunitas nelayan dan sangat sejalan dengan prinsip-prinsip konservasi sumberdaya perikanan.

\section{Kesimpulan}

Praktik ritual yang berasosiasi dengan kepercayaan serta ungkapan-ungkapan berupa pamali pada komunitas nelayan Pulau Kambuno merupakan tata kelakuan yang menjadi aturan-aturan ide, gagasan serta nilai-nilai yang terikat dalam suatu kesatuan budaya yang mencakup, yaitu (1) pola bersikap yang mendapat isi dari pengarahan dari nilai-nilai budaya, (2) pola bertindak dalam kegiatan komunitas nelayan, dan (3) pola sarana benda-benda (fisik). Tiga wujud budaya tersebut merupakan jiwa, organisasi, dan teknologi sebagai tata tertib yang dijaga eksistensinya dalam keselarasan antara mikro kosmos dengan makro kosmos yang sekaligus mempersatukan segenap komunitas nelayan.

Pola kebudayaan yang diadaptasi nelayan Pulau Kambuno merupakan praktik tradisi yang terwarisi dari generasi ke generasi berikutnya sambil melakukan penyesuain-penyesuaian seiring dengan perkembangan zaman. Pengintegrasian kepercayaan dan pamali sebagai pengetahuan lokal nelayan dengan ilmu pengetahuan (science) menjadi penting dilakukan sebagai upaya pengembangan dan perubahan pengetahuan dan teknologi nelayan pulau kecil ke arah yang lebih sesuai dengan tuntutan perubahan, khususnya perubahan tingkah laku dalam mengelola usaha perikanan tangkap menjadi lebih efisien dan lebih efektif sesuai dengan tuntutan perubahan zaman.

\section{Daftar Pustaka}

Aisyah, S. (2020). Makna dan Fungsi Pamali Masyarakat Suku paser Kecamatan Long Ikis Kabupaten Paser (The Meaning And Function Of Practical Community Interest Paser District Long Acts Paser). Jurnal Bahasa, Sastra Dan Pembelajarannya, 10(2).

Alains, A. M., Putri, S. E., \& Haliawan, P. (2009). Pengelolaan sumberdaya perikanan berbasis masyarakat (PSPBM) melalui model comanagement perikanan. Jurnal Ekonomi Pembangunan: Kajian Masalah Ekonomi Dan Pembangunan, 10(2), 172-198.

Arief, A. A. (2007). Artikulasi Modernisasi dan Dinamika Formasi Sosial Pada Nelayan Kepulauan di Sulawesi Selatan (Studi Kasus Nelayan Pulau Kambuno). Penelitian Disertasi (Tidak Dipublikasikan).

Arief, A. A., Agusanty, H., \& Mustafa, M. D. (2020). Fishermen Conflict and the Resolution for Using Fisheries Resources Utilization at Selayar Islands, South Sulawesi. ECSOFiM (Economic and Social of Fisheries and Marine Journal), 7(2), 228-238.

Babbie, E. (2004). The Practice of Social Research. USA: Thomson Wadsworth.

Ibrahim, I. (2018). Sistem Kepercayaan 
Sebagai Basis-Struktur Sosial Masyarakat Nelayan Liukang Tupabbiring di Kabupaten Pangkep. AlQalam, 16(2), 141-152.

Isnendes, R. (2014). Estetika Sunda sebagai bentuk kearifan lokal masyarakat sunda tradisional dalam sawangan pendidikan karakter. Edusentris, 1(2), 194-206.

Jumardi, N., Djafar, S., \& Tamsil, A. (2018). Strategi Pengembangan Mata Pencaharian Alternatif Untuk Meningkatkan Pendapatan Rumah Tangga Nelayan di Pulau Kodingareng Kota Makassar. Journal Of Indonesian Tropical Fisheries (Joint-Fish): Jurnal Akuakultur, Teknologi Dan Manajemen Perikanan Tangkap, Ilmu Kelautan, 1(1), 49-58.

Harpriyanti, H., \& Komalasari, I. (2018). Makna dan Nilai Pendidikan Pamali Dalam Masyarakat Banjar di Desa Barikin Kabupaten Hulu Sungai Tengahle. Stilistika: Jurnal Bahasa, Sastra, Dan Pengajarannya, 3(2). https://jurnal.stkipbjm.ac.id/index.php/ STI/article/view/962

Lampe, M. (2012). Bugis-Makassar Seamanship and Reproduction of Maritime Cultural Values in Indonesia. Humaniora, 24(2), 121-132.

Miles, M.B, Huberman, A.M, dan Saldana, J. (2014). Qualitative Data Analysis, A Methods Sourcebook, Edition 3. USA: Sage Publications.

Nurdiansah, N. (2017). Budaya Pamali Sebagai Landasan Pembelajaran Lingkungan di Sekolah Dasar (Studi Kasus Pada Masyarakat Adat Kampung Naga Tasikmalaya). Pedagogi: Jurnal Penelitian Pendidikan, 4(1).

Nurhayati, U., \& Nurkholik, N. (2018). The Morphological Processes of Bugis Language (A Morphological Study Of Bugis Language Through Latoa Script). IDEAS: Journal on English Language Teaching and Learning, Linguistics and
Literature, 6(1).

Sarmidi, G. (2015). Keberadaan Wacana Pantang Larang Berlaras Gender Sebagai Tradisi Lisan, Fenomena Bahasa, dan Sastra Lisan di Indonesia. Jurnal Inspirasi Pendidikan, 5(1), 553559.

Selasih, N. N., \& Sudarsana, I. K. (2018). Education Based on Ethnopedagogy in Maintaining and Conserving the Local Wisdom: A Literature Study. Jurnal Ilmiah Peuradeun, 6(2), 293-306.

Subagiyo, A., Wijayanti, W. P., \& Zakiyah, D. M. (2017). Pengelolaan Wilayah Pesisir dan Pulau-Pulau Kecil. Universitas Brawijaya Press.

Susanti, J. T., \& Lestari, D. E. G. (2020). Tradisi Ruwatan Jawa pada Masyarakat Desa Pulungdowo Malang. Jurnal Satwika, 4(2), 94-105.

Taufiq, T. T. (2018). Kearifan Lingkungan Berbasis Agama (Studi Etnoekologi Komunitas Nelayan di Pesisir Banyutowo Dukuhseti Pati). Jurnal Sosiologi Agama, 11(2), 259-280. 